\title{
Consumer Perception of Online Marketplace in Bangladesh: An Empirical Study on Dhaka City
}

\author{
Most. Moriom Khatun ${ }^{1}$, Noor M Rahamatullah ${ }^{2}$, Tanjina Afrin ${ }^{3}$, Safiul Islam ${ }^{4}$, Mofasser Rahman \\ 1,3,4,5 Department of Agribusiness and Marketing, Sher-e-Bangla Agricultural University, BANGLADESH \\ ${ }^{2}$ Department of Agricultural Statistics, Sher-e-Bangla Agricultural University, BANGLADESH
}

"E-mail for correspondence: moriom.rima@gmail.com

https://doi.org/10.18034/abr.v10i2.473

\begin{abstract}
Bangladesh is one of the growing economically developing countries, where the online marketplace is becoming popular in recent days. Besides the traditional market or super shops, online marketplaces grab the eyeballs of the consumers, because of avoiding a heavy traffic jam, huge time consuming, public gathering, and recent Covid-19 lockdown. This paper conducted an empirical study to measure the consumer perception of the online marketplace. The relationship between consumer preference and demographic data is also analyzed. It has been found that major responders are young in age, male in gender, and student and jobholders in occupation. Whereas, books and foods are the main preferred product to purchase online because those twos are reliable and easy to ensure quality rather than clothing, cosmetics, and other products. A suggestion would be concluded by this paper is that products in the online marketplace must increase the quality and reliability to ensure the purchasing preference by the consumers.
\end{abstract}

Key words: Consumer Perception, Digital Marketing, E-commerce

\section{INTRODUCTION}

Digital marketing is the utilization of electronic media by the marketers to promote the products or services into the market. It is one of the current trends not only in Bangladesh but also all over the world. Consumers and business owners in Bangladesh are facing several new challenges and problems in the digital age. However, there still have some opportunities and strength for using digital marketing such as increasing Smartphone usages, Government Internet promotion, popularity of native advertising, etc (Ohidujjaman et al., 2013). It has been found that marketing strategies are changed to adopt the digital age such as several online-based home delivery (chaldal.com, foodpanda.com, aarong.com, etc) are took place in Business to Consumer. Users are also using digital market places such as Bikroy.com, olx.com, othoba.com, etc. in Consumer to Consumer business type.

Bangladesh, as a country with a vast population, is full of potentials. Information Technology is the key to utilize those potentials. From 2009, Bangladesh has been experiencing numerous ground breaking developments in IT sector. According to the BASIS (Digital Marketing
Summit: Annual event organized by Bangladesh Brand Forum, Last Accessed: 27 April, 2019, URL:http://dms2015.bbf.digital) survey the ICT industry has consistently grown in recent years at 20 to 30 percent per annum. Over 800 registered ICT companies generated total revenues of approximately $\$ 250$ million. More than 75 percent of companies are involved in customized application development and maintenance, 50 percent are dedicated to IT enabled services, and 45 percent offer Ecommerce/Web services. The survey also shows that 60 percent of companies solely focus on the domestic market.

This study analyses the current status, challenges and opportunities of digital marketing in Bangladesh. Questioners were developed based on dichotomous, multiple choice, and demographic survey style for collecting data on digital marketing in Bangladesh. Randomly 150 respondents were surveyed for completing that digital marketing survey. It has been found that maximum respondents are male (about $73 \%$ ), and major respondents are young in age (20 to 40 years) which about $77 \%$. It is good to find that, almost every people are conscious about digital marketing and maximum 
respondents prefer online marketing which about $79 \%$. Several significant bivariate relationships among collected data has also been found.

To reach the sky on digital marketing in Bangladesh, several recommendations are suggested such as the infrastructure should be developed so that digital media resources will be easily available; bringing international payment service providers' such as PayPal, Visa, etc. Finally it can be concluded that digital marketing brings the greatest advantage for the consumers by allowing them to make comparison among products or services. It is the time to bring all stakeholders including government, business, advertisement agencies, media and technology players under a same platform to promote digital marketing practices in Bangladesh. Rest of the journal is organized as follows: Chapter 2 describes literature review on consumer perception of online business as well as Bangladeshi marketplace. The methodology and data collection of this study will be presented in Chapter 3 . Result analysis and discussions are presented in Chapter 4. Finally conclusion is depicted in Chapter 5.

\section{LITERATURE STUDY}

Several literatures have been studied on customer perception on digital or online marketing including the customer behaviors, awareness of digital marketing, purchasing history, purchasing preference, etc. An overview of the studied literature review has been depicted at Table 1.

Shawon and others presented factor analysis for online purchasing behavior among Bangladeshi young generation (Shawon et al., 2018). They also analyzed several risk factors for calculating the influence attitude towards shopping online behavior. They also conceptualized a model to determine the effects and finalized that online marketplace payment system should be more secure and put more emphasis on product delivery.
Hossain, T. depicted a study on women entrepreneur in Dhaka city through e-business which is actually an implication of digital market place (Hossain, 2018). This paper also evaluated the effectiveness of e-business on the empowerment of women. They have collected data through a semi-structured questionnaire, and found out that three major factors are related to e-business named are (1) Economic Freedom, (2) Greater social independency \& acceptability, and (3) Sense of self-worth.

Haque and others analyzed a study on Bangladeshi consumer perspective for purchase intent of foreign products (Haque et al., 2015). They have collected 260 Bangladeshi consumers residing in the two major cities of the county. They have found that brand image and foreign products' quality carry significant positive influence on purchase intention of foreign products. On the other hand religiosity leaves a significant negative effect on the purchase intention.

Rahman, S.M. presented an investigation of Millennial also known as Generation $\mathrm{Y}$ in Bangladesh (Rahman, 2015). They tried to find out this generational consumer expectation from online retailers in developing ecommerce market. They also examined the similarities and dissimilarities between the target group and the global online retail market trends. They have studied several data and found that 'Clothing and footwear' and 'Jewelries and Watches' are the most wanted purchase item by male and female respectively.

Hoque F. et al presented an empirical study customer perception on purchasing through Facebook in Bangladesh (Hoque, 2020). The study conducted on the capital of Bangladesh and analyzed the peoples view point to purchase product via Facebook. They found that cash on delivery, after purchasing management, and others factors have significantly positive impact on purchasing history.

Table 1: Overview of the Literature Review

\begin{tabular}{|c|c|l|c|l|}
\hline S1 & Author & Title & Year & Keywords \\
\hline $\mathbf{1}$ & Haque et al. (2015) & $\begin{array}{l}\text { Purchase intention of foreign products: A study on } \\
\text { Bangladeshi consumer perspective. }\end{array}$ & 2015 & $\begin{array}{l}\text { Consumer perspective, foreign } \\
\text { products, purchase intention }\end{array}$ \\
\hline $\mathbf{2}$ & Hoque et al. (2020) & $\begin{array}{l}\text { Customer Perception on Purchasing through Facebook } \\
\text { in Bangladesh: An Empirical Study on Dhaka City }\end{array}$ & 2020 & $\begin{array}{l}\text { Consumer perception, Facebook } \\
\text { marketing, Bangladesh }\end{array}$ \\
\hline $\mathbf{3}$ & Hossain (2018) & $\begin{array}{l}\text { Online Purchasing Behavior among Bangladeshi Young } \\
\text { Generation: Influencing Factors and Impact }\end{array}$ & 2018 & $\begin{array}{l}\text { e-business, Entrepreneurship, } \\
\text { Self-worth, Bangladesh }\end{array}$ \\
\hline $\mathbf{4 .}$ & $\begin{array}{c}\text { Karim and Qi } \\
(2018)\end{array}$ & E-commerce Development in Bangladesh & 2018 & $\begin{array}{l}\text { e-commerce, Bangladesh, } \\
\text { consumer attitude }\end{array}$ \\
\hline $\mathbf{5}$ & $\begin{array}{c}\text { Kumar (2019) } \\
\text { Consumer perception, e- } \\
\text { commerce. }\end{array}$ \\
\hline $\mathbf{6}$ & $\begin{array}{c}\text { Rahman (2015) } \\
\text { Consumer perception towards e-commerce in India }\end{array}$ & $\begin{array}{l}\text { Consumer expectation from online retailers in } \\
\text { developing e-commerce market: An investigation of } \\
\text { generation Y in Bangladesh. }\end{array}$ & 2019 & $\begin{array}{l}\text { e-commerce, e-business, online } \\
\text { consumer behavior, generation } \\
\text { Y }\end{array}$ \\
\hline $\begin{array}{c}\text { Shawon et al., } \\
(2018)\end{array}$ & $\begin{array}{l}\text { Online Purchasing Behavior among Bangladeshi Young } \\
\text { Generation: Influencing Factors and Impact }\end{array}$ & 2018 & $\begin{array}{l}\text { Online shopping, Product Risk, } \\
\text { Return Policy, Bangladesh }\end{array}$ \\
\hline
\end{tabular}


Karim and Qi presented the characteristics of Bangladesh ecommerce, its past and present development (Karim and Qi, 2018). This paper conducted to know the perception of online consumers with their previous shopping experience. Based on the survey data analysis authors concluded that the consumers of Bangladesh shown positive attitudes on e-shopping with the concern of safety and privacy. They also found that consumers and merchants have a lack of knowledge about the whole business system, which needs to be resolved by government actions.

\section{MetHodologY}

This paper conducts research to identify the consumer perception for online product purchasing. To determine the findings some research question have been selected which are listed below.

[RQ1] Which types of products are purchased in online by consumers with variance of age \& gender?

[RQ2] Which types of products are purchased in online by consumers with variance of occupation and education?

To point out those questions, we have created a questionnaire and collected data using a survey. The data collection details are follows.

- $\quad$ Target group: General People (Dhaka City)

- Age group: 20 years to 65 years

- Gender: Both male and female

- Sample Size: 150 respondents

\section{FINDINGS AND ANALYSIS}

\section{Univariate Data Analysis}

Gender of the Respondents: The overall e-commerce activity in terms of gender and compare the males vs. female ratio for e-commerce in Bangladesh presented in Figure 1. The research observed that out of the total ecommerce activities carried out, $70 \%$ comprised of males, with females involved in only $30 \%$ of the total. However, the average e-commerce conversion rate between the two genders was nearly similar. E-commerce conversion rate is the percentage of website visitors that actually buy online. For example, if a hundred visitors landed on a website and only two of them purchased the product, the e-Commerce conversion rate would be $2 \%$

The age of the respondents: According to a recent research study by an online buy-sell platform, the population falls between the age brackets of 20-30 years account for the highest number of users, with the 31-40 and 41-50 brackets falling at second and third places respectively. One of the most significant reasons for this observation is the fact that people falling in the age bracket of 21-30 years are more inclined towards technology and its usage. These people are at the forefront of the technological revolution and are more open to online shopping. Details are presented in Figure 2.
Educational Background of the respondents: Educational background has been chosen as a factor for data analysis. Educational background has been categorized by five sections named as S.S.C, H.S.C, Undergraduate (BSc/BA), Graduate (MS/PhD), and others presented in Figure 3. The findings of those sectors are $28 \%, 15 \%, 37 \%, 5 \%$, and $15 \%$ respectively. It is found that educated persons are more active than any others in the digital marketing of Bangladesh. The Occupation of the respondents: The responders are categorized into several sectors named as Businessman, Doctor, Engineer, Farmer, Housewife, Job Holder, Student, Teacher, and Others, presented in Figure 4 . It has been analyzed that the maximum percentage of responders are Students which is 31\%. Besides this, Businessman, Doctor, Engineer, Farmer, Housewife, Job Holder, Teacher, and Other category percentages are 5\%, $13 \%, 8 \%, 3 \%, 4 \%, 22 \%, 7 \%$, and $8 \%$ respectively.

Preferred Product in Digital Marketplace: Most Interesting Product in Digital Marketplace has been chosen as a factor for data analysis. Most Interesting Product in Digital Marketplace has been categorized by four sections named Book, Clothing, Electronics, Food, and others presented in Figure 5. The findings of those sectors are $40 \%, 25 \%, 17 \%$, $15 \%$, and $3 \%$ respectively. It is found that the book is the toprated product in the digital marketplace.

\section{Gender of the Respondents}

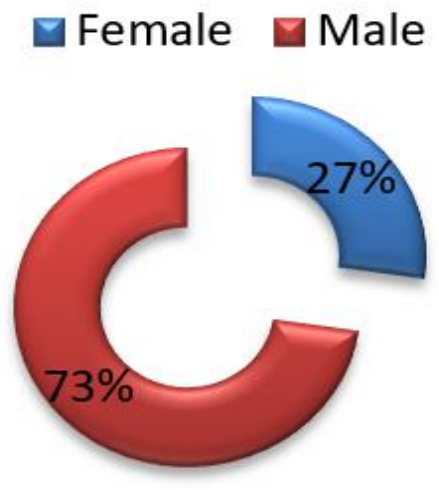

Figure 1: Gender Classification of Respondents

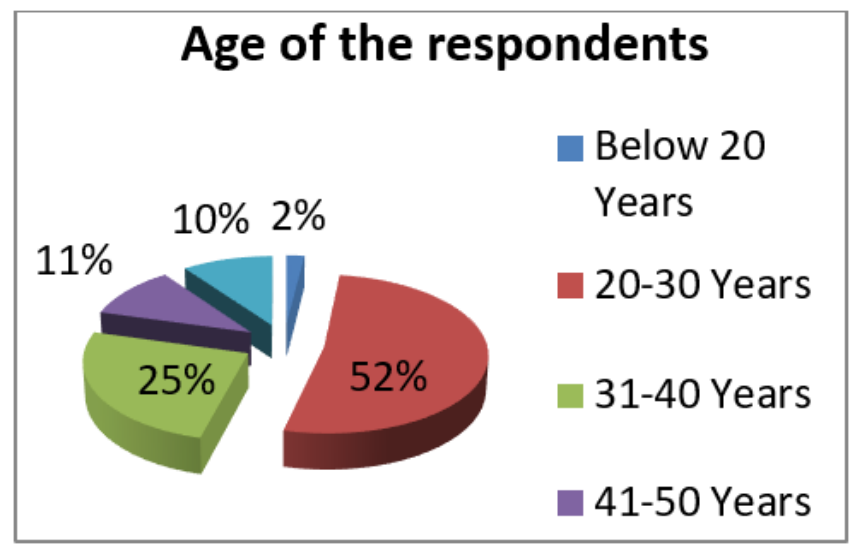

Figure 2: Age Distribution of Respondents 


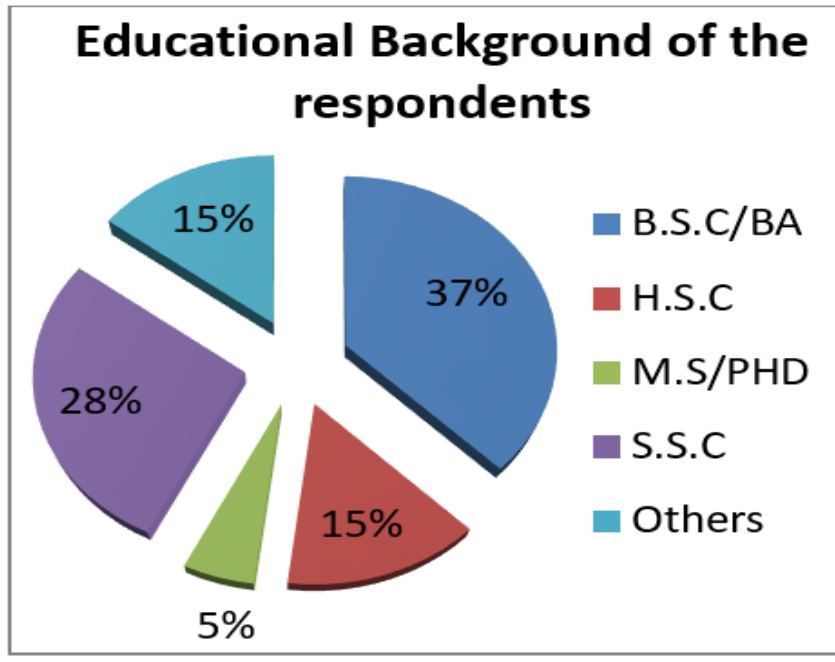

Figure 3: Educational Background of Respondents

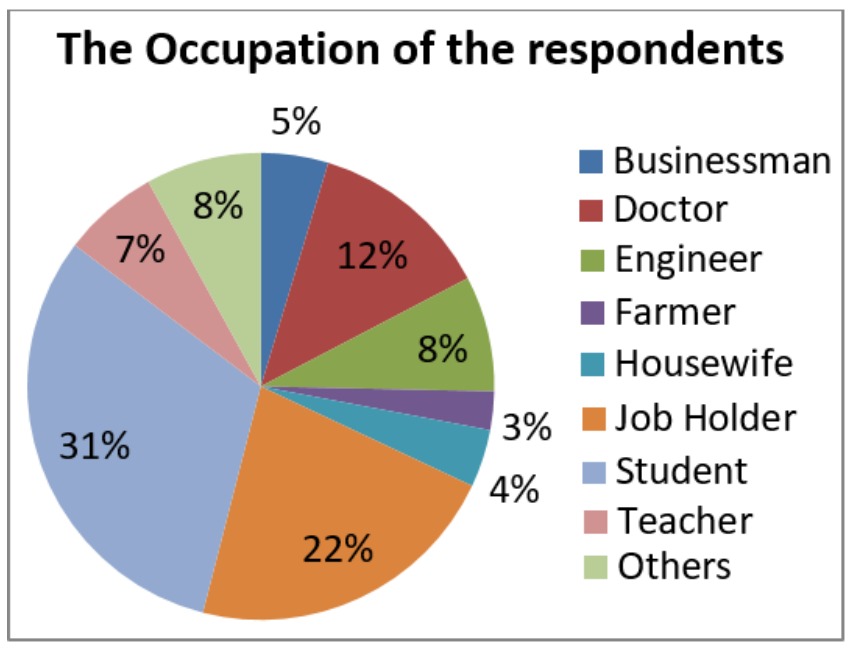

Figure 4: Occupation of the Respondents

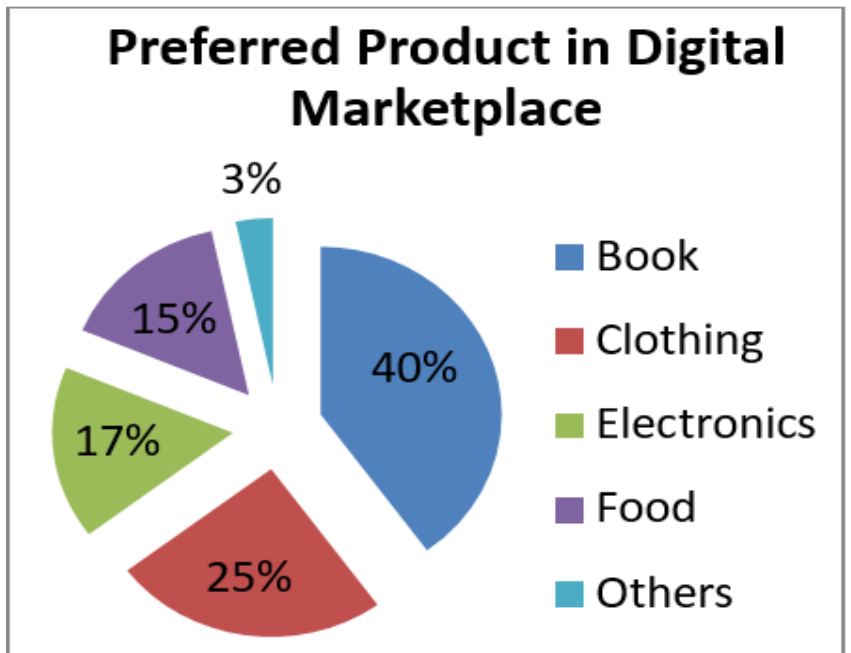

Figure 5: Preferred Product in Online Marketplace

Bivariate Data Analysis

[Answer of RQ1]

Which types of products are purchased in online by consumers with variance of age \& gender? Based on the survey data analysis, it is clearly pointed out that Book is the most preferred product which have maximum purchase ration for all age and gender. This might happen that, when consumers buy books, they frequently confirm their purchase. On the other hand, consumers often ignore to confirm their preferred product (cloth/food/others) after adding them to craft, because of quality insurance. The analyzed results are presented at Figure 6. It also found that, young responders below 49 are the maximum numbers and always prefer book and cloths. Whereas, responders age 50+ are the lowest who like to order only book and foods.

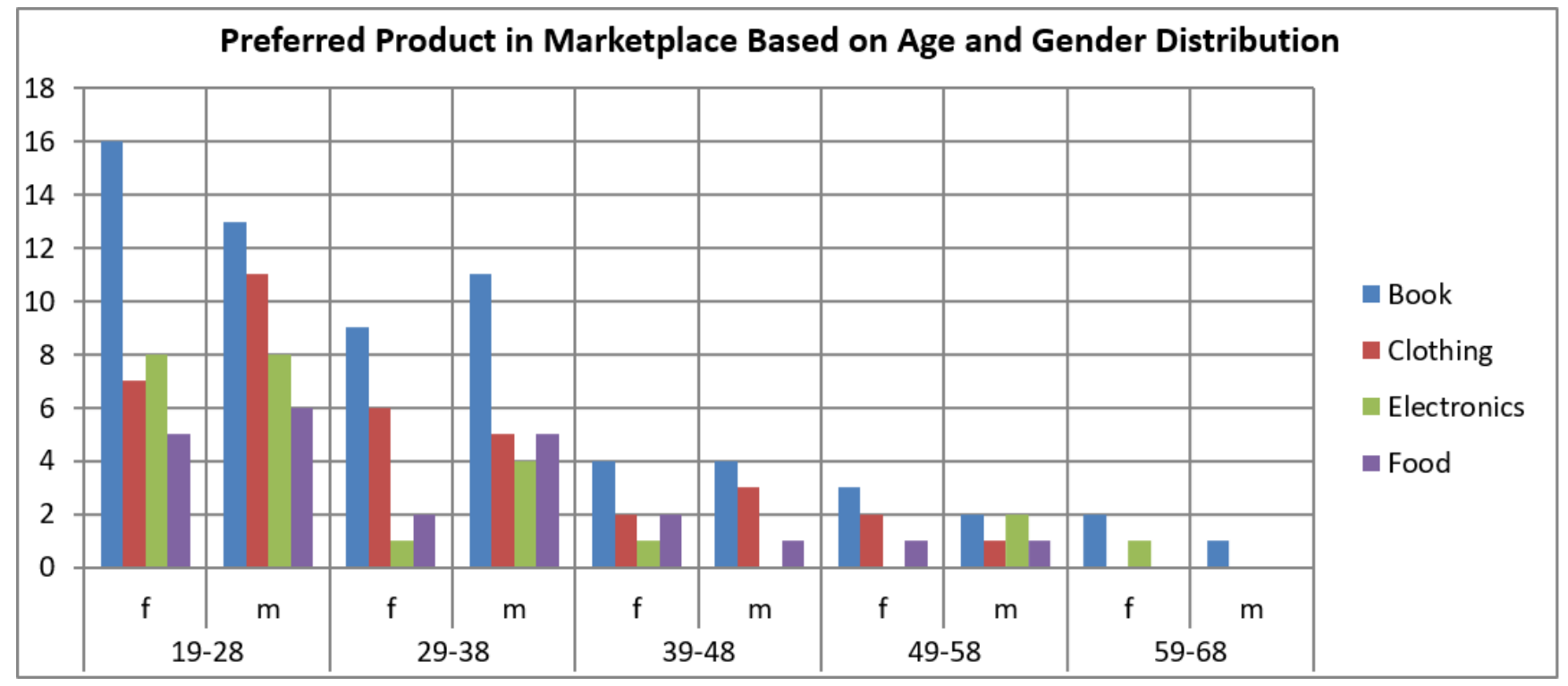

Figure 6: Preferred Product in Marketplace Based on Age and Gender Distribution 


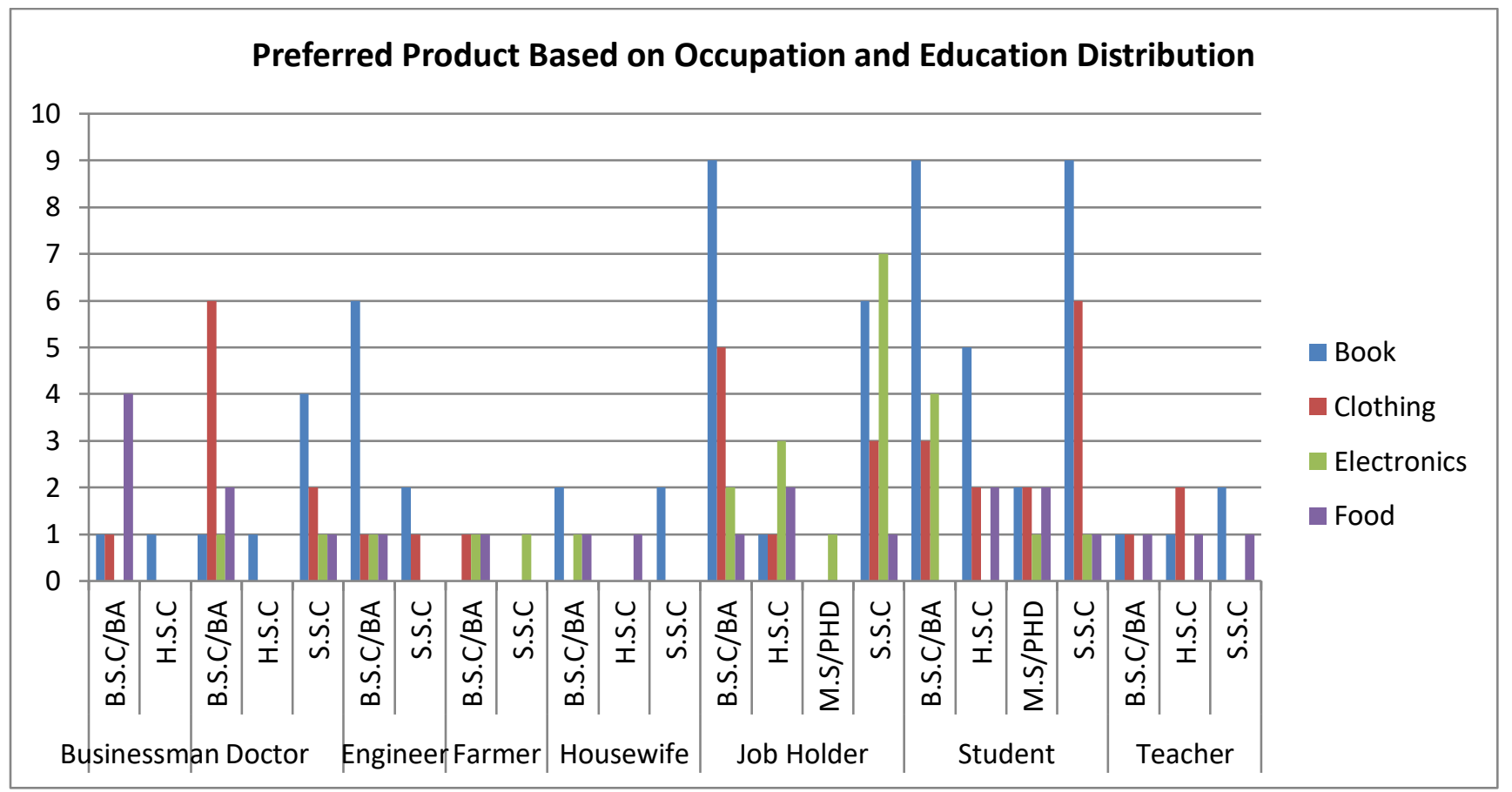

Figure 7: Preferred Product in Marketplace Based on Occupation and Education Distribution

\section{[Answer of RQ2]}

Which types of products are purchased in online by consumers with variance of occupation and education? After analyzing the data, it can be concluded Book and Food are the two most preferred products by consumers. Details results are presented at Figure 7. It also found that, Students and Job holder are the maximum number of consumers to order in online marketplace. However, farmer, housewife and teachers are in the bottom in online product purchasing.

\section{Conclusion}

This paper presented an empirical study on consumer perception towards the digital marketplaces in Bangladesh. Total 150 responders are analyzed to determine the preferred products based on age, gender, occupation and educational variation. It has been demonstrated that young age (between 19 to 38 years) are the main responders who always prefer to buy books and food. Whereas, based on occupational distribution, students and job holders are the maximum consumers who preferred books, cloths and foods accordingly. However, no significant difference has been found between male and female preference to purchase.

\section{REFERENCES}

Haque, A., Anwar, N., Yasmin, F., Sarwar, A., Ibrahim, Z., \& Momen, A. (2015). Purchase Intention of Foreign Products: A Study on Bangladeshi Consumer Perspective. SAGE Open. https:// doi.org/10.1177/2158244015592680
Ohidujjaman, Hasan, M. and Huda, M.N. (2013). E-commerce Challenges, Solutions and Effectiveness Perspective Bangladesh. International Journal of Computer Applications, 70(9):917, https://doi.org/10.5120/11989-7867

Hoque, F.; Joya, T.A.; Akter, A.; Afrina, T.; Beg, T.H.; Mukul, A.Z.A. (2020). Customer Perception on Purchasing Through Facebook in Bangladesh: An Empirical Study on Dhaka City, Academy of Marketing Studies Journal, Volume 24, Issue 2, 1-14.

Hossain, T. (2018). Empowering Women through E-Business: A Study on Women Entrepreneurs in Dhaka City. Asian Business Review, 8(3), Art. \#21, pp. 153-160. https://doi.org/10.18034/abr.v8i3.167

Karim, T., \& Qi, X. (2018). E-commerce Development in Bangladesh. International Business Research, 11, 201-211. https://doi.org/10.5539/ibr.v11n11p201

Kumar, A. (2019). Consumer perception towards e-commerce in India. ZENITH International Journal of Multidisciplinary Research, 9(4), 120-128.

Rahman, S.M. (2015). Consumer expectation from online retailers in developing e-commerce market: An investigation of generation $\mathrm{Y}$ in Bangladesh. . International Business Research. 8(7), 121-130. https://doi.org/10.5539/ibr.v8n7p121

Shawon, S. S., Hasan, M. A., Nayeem, A. R., \& Uddin, M. B. (2018). Online Purchasing Behavior among Bangladeshi Young Generation: Influencing Factors and Impact. Asian Business Review, 8(3), Art. \#17, pp. 123-128. https://doi.org/10.18034/abr.v8i3.163

$--0-$ 


\section{How to cite this article:}

Khatun, M. M., Rahamatullah, N. M., Afrin, T., Islam, S., \& Rahman, M. (2020). Consumer Perception of Online Marketplace in Bangladesh: An Empirical Study on Dhaka City. Asian Business Review, 10(2), 115-120. https://doi.org/10.18034/abr.v10i2.473 